\title{
Peningkatan Rasa Kesadaran Bahaya Minuman Keras dengan Pendekatan Eksperimen Melalui PPL-KKM di SDN 11 Bora Desa Kecamatan Sayan Kabupaten Melawi
}

\author{
Nelly Wedyawati ${ }^{1}$, Yasinta lisa ${ }^{2}$ \\ ${ }^{1}$ Program Studi PGSD STKIP Persada Khatulistiwa Sintang \\ ${ }^{3}$ Program Studi Pendidikan Komputer STKIP Persada Khatulistiwa Sintang \\ e-mail: ${ }^{1}$ nellywedyawati@ymail.com, ${ }^{2}$ yasintalisa@gmail.com
}

\begin{abstract}
Tuak is a typical drink of the Dayak tribe in West Kalimantan, which is a result of fermentation from sap or glutinous rice. Tuak is not made every day, the manufacture is specifically for ceremonies or traditional parties, for example at wedding parties, harvesting rice, welcoming guests etc. Basically the tradition of drinking tuak symbolizes the spirit of togetherness, family and friendship. Drinking large amounts of tuak will be intoxicating. The survey results from 100 students at the elementary school level, 100 of them were familiar with tuak / arak liquor. 80 children know their parents consume wine / palm wine. 80 children assume that they may consume Arak / Tuak and only 26 students whose parents are angry if the child consumes wine / palm wine. The purpose of this activity is to empower the potential of students to increase the awareness of the dangers of palm wine for health by an experimental approach to the target community of activities. The experimental approach is considered suitable, because through observation, experience and direct observation of the target audience. Preparation of activities with training and assistance in making LKS and KIT to students. At the implementation stage carried out with simulations and experiments directly together with the target audience. The final results of the activity showed that $60 \%$ of participants had a change in understanding of the dangers of consuming liquor measured by a questionnaire. Statement of satisfaction from training participants (students), target communities and local government. The results of the activity resulted in $99 \%$ of students present at the training, 100\% of students experienced an increased understanding of the dangers of drinking alcohol for the body and 100\% of activities received by the target activity.
\end{abstract}

Keywords: Tuak, Arak, Danger of Liquor, Experimental Approach

Abstrak:Tuak adalah minuman khas suku Dayak di Kalimantan Barat, yang merupakan hasil fermentasi dari nira atau beras ketan. Tuak tidak dibuat setiap hari, pembuatannya dikhususnya untuk upacara atau pesta adat, misalnya saat pesta perkawinan, panen padi, penyambutan tamu dsb. Pada dasarnya tradisi minum tuak ini melambangkan semangat kebersamaan, kekeluargaan dan persahabatan. Minum tuak dalam jumlah yang besar akan memabukkan. Hasil survey dari 100 peserta didik jenjang sekolah dasar, 100 mengenal minuman keras jenis tuak/arak. 80 orang anak tahu orangtuanya mengkonsumsi arak/tuak. 80 orang anak beranggapan bahwa mereka boleh mengkonsumsi Arak/Tuak dan hanya 26 siswa yang orangtuanya marah jika anak mengkonsumsi arak/tuak. Tujuan kegiatan ini untuk memberdayakan potensi mahasiswa meningkatkan kesadaran bahaya minuman keras tuak bagi kesehatan dengan pendekatan eksperimen kepada masyarakat sasaran kegiatan. Pendekatan eksperimen dianggap cocok, karena melalui pengamatan, pengalaman dan observasi langsung khalayak sasaran. Persiapan kegiatan dengan pelatihan dan pendampingan pembuatan LKS dan KIT kepada mahasiswa. Pada tahapan pelaksanaan dilakukan dengan simulasi dan 
http:/jumal.stkippersada.ac:id/jumal/index:php/JP:M

eksperimen langsung bersama dengan khalayak sasaran. Hasil akhir kegiatan menunjukkan bahwa $60 \%$ peserta memiliki perubahan pemahaman tentang bahaya mengkonsumi minuman keras diukur dengan angket. Pernyataan kepuasaan dari peserta pelatihan (mahasiswa), masyarakat sasaran dan pemerintah setempat. Hasil kegiatan menghasilkan $99 \%$ mahasiswa hadir pada saat pelatihan, $100 \%$ siswa mengalami peningkatan pemahaman bahaya konsumsi miras bagi tubuh dan $100 \%$ kegiatan diterima oleh sasaran kegiatan.

Kata kunci-Tuak, Arak, Bahaya Minuman Keras, Pendekatan Eksperimen 


\section{PENDAHULUAN}

Orang Dayak ini suka menjamu tamunya, sebaiknya jangan menolak makanan yang disajikan walaupun itu sederhana. Orang Dayak akan malu jika tamunya sampai mengalami kelaparan. Bahkan dianggap sebagai tuan rumah yang tidak baik, walaupun anda sudah bilang "sudah kenyang pasti anda tetap akan disuguhi makanan. Jamuan oleh orang dayak adalah dengan makanan, sirih dan tuak. Dulu minuman ini atau yang di sebut Tuak/Bram/Beram adalah suguhan pengganti teh/kopi bagi kalangan masyarakat Dayak umumnya. Jauh sebelum mengenal teh/kopi, suku Dayak sudah bisa membuat Tuak dengan rasa manis sedikit berbisa/hangat/keras alami sebagai akibat dari proses fermentasi atau peragian dari beras pulut/ketan yang di buat tapai.

Dalam tradisinya, tuak sendiri digunakan sebagai suguhan ketika ada tamu datang ke bilik (dalam rumah betang) baik pagi, siang maupun malam. Setiap bilik selalu menyiapkan tuak, selain untuk diri sendiri maupun tamu. Minuman ini juga berfungsi sebagai penghangat badan kala itu. Pada acara kebudayaan seperti gawai atau pesta pernikahan, tuak adalah minuman pelengkap yang harus ada.

Tuak adalah sejenis minuman beralkohol Nusantara yang merupakan hasil fermentasi dari nira, beras, atau bahan minuman/buah yang mengandung gula. Tuak adalah produk minuman yang mengandung alkohol. Bahan baku yang biasa dipakai adalah: beras atau cairan yang diambil dari tanaman seperti nira pohon enau atau nipah, atau sumber lain. Kadar alkohol tuak di pasaran berbeda-beda bergantung daerah pembuatnya. Tuak beras adalah sejenis minuman masyarakat di Kalimantan. Biasanya tuak beras diolah dari sejenis beras yang disebut "beras pulut" (beras ketan). Beras tersebut akan direndam air di dalam tempayan yang disebut "Tajau". Proses tersebut akan mengambil waktu setidaknya dua minggu sebelum dapat diminum dan beras tersebut juga akan menjadi makanan yang disebut "tapai". Namun saat ini proses pembuatan tuak beras berlainan sedikit, yaitu selain dibuat menggunakan beras ketan, juga dicampur dengan gula pasir supaya rasanya lebih manis. Tuak jenis ini memiliki kandungan alkohol yang cukup untuk membuat mabuk bila diminum berlebihan.

Konsumsi minuman beralkohol yang berlebihan dan dalam jangka waktu dapat merusak beberapa fungsi organ tubuh secara permanen. Alkohol dapat memperbesar ginjal sehingga mempengaruhi fungsi hormon normal tubuh. Menimbulkan tekanan darah menjadi tinggi sehingga mempengaruhi kinerja jantung. Mempengaruhi tingkat kolesterol baik dalam tubuh dan meningkatkan akumulasi lemak di hati sehingga mempengaruhi fungsi hati. Sifat alkohol yang mudah melarutkan, dapat merusak ketajaman penglihatan. Sebenarnya sel-sel saraf kita sudah dilindungi lapisan lemak namun saat meminum alkohol, lapisan lemak yang melindungi sel saraf akan larut dan akibatnya sel-sel saraf menjadi rusak. Alkohol juga merupakan pemicu kanker payudara pada wanita. Mengkonsumsi alkohol berlebihan mempengaruhi sistem saraf dengan menghambat distribusi sinyal antara saraf tulang belakang dengan otak. Akibat yang ditimbulkan memicu mati rasa, koordinasi tubuh seseorang menjadi tumpul. Kurangnya koordinasi dan perilaku yang tidak terkontrol merupakan efek paling terlihat ketika seseorang mabuk.

Jumlah kasus kejahatan semakin meningkat di Indonesia. Minuman keras (Miras) 
http://jurnalstkippersada.acid/jurnal/index:php/JPMR dinilai sebagai penyebab bertambahnya kasus kriminal belakangan ini.

$$
\text { Riset Kesehatan Dasar (Riskesdas) }
$$

Kementerian Kesehatan 2007 mencatat, remaja pengonsumsi miras di Indonesia masih di angka 4,9 persen. Jumlah ini meningkat signifikan pada 2014 menjadi 23 persen dari total jumlah remaja sekitar 14,4 juta jiwa, berdasarkan riset Gerakan Nasional Anti Miras (GeNAM). "Remaja yang mengonsumsi miras cenderung berperilaku negatif. Memang faktor ini (miras) bukan satu-satunya, ada sebuah mata rantai yang sudah sangat kompleks, seperti pornografi dan tayangan yang tidak mendidik.

Pada tahun 2015 di Desa Kemangai Kecamatan Ambalau Kabupaten Sintang, survey tentang pengetahuan peserta didik tentang minuman keras tuak di kelas III (31 siswa), IV (32 siswa), dan V (37 siswa) berjumlah Sekolah Dasar berjumlah ditemukan fakta yang disajikan pada tabel 1 sebagai berikut:

Tabel 1. Hasil survey tentang minuman keras di Desa Kemangai

\begin{tabular}{|c|c|c|c|c|c|}
\hline \multirow{3}{*}{ No } & \multirow{3}{*}{ Indikator } & \multicolumn{3}{|c|}{ Jawaban ya } & \multirow{3}{*}{ Persentase } \\
\hline & & \multicolumn{3}{|c|}{ Kelas } & \\
\hline & & III & IV & $\mathrm{V}$ & \\
\hline 1 & $\begin{array}{l}\text { mengetahui } \\
\text { minuman keras } \\
\text { jenis Tuak/Arak. }\end{array}$ & 31 & 32 & 37 & $100 \%$ \\
\hline 2 & $\begin{array}{l}\text { Orangtua } \\
\text { mengkonsumsi } \\
\text { Arak/Tuak }\end{array}$ & 25 & 25 & 30 & $80 \%$ \\
\hline 3 & $\begin{array}{l}\text { Anak-anak boleh } \\
\text { mengkonsumsi } \\
\text { Arak/Tuak }\end{array}$ & 20 & 29 & 36 & $85 \%$ \\
\hline 4 & $\begin{array}{l}\text { Orangtua marah } \\
\text { jika anak } \\
\text { mengkonsumsi } \\
\text { arak/tuak }\end{array}$ & 15 & 5 & 6 & $26 \%$ \\
\hline & Jumlah pe & & 1 & . & \\
\hline
\end{tabular}

Berdasarkan budaya minum Tuak pada masyarakat suku dayak dan bahaya miras lainnya pagi kesehatan tubuh maka sangat
e-ISSN 2580-5800

penting melakukan upaya bagi generasi penerus agar mengetahui bagaimana minuman keras dapat merusak sistem organ. Upaya tersebut dalam kegiatan pengabdian dilakukan dengan pendekatan eksperimen agar para peserta didik dan masyarakat melihat langsung simulasi dan memiliki pengalaman nyata bagaimana minuman tersebut dapat merusak sistem organ.

\section{METODE}

Pelaksanaan kegiatan dilakukan untuk mencapai target yang direncanakan, sebelum mahasiswa PGSD terjun ke objek sasaran terlebih dahulu mahasiswa diberi bekal pengetahuan dasar tentang pembuatan KIT IPA sebagai pendekatan praktikum guna menunjukkan bahaya minuman keras bagi tubuh manusia melalui kegiatan pelatihan kit IPA sebagai pendekatan praktikum guna menunjukkan bahaya minuman keras bagi tubuh manusia melalui kegiatan pelatihan dan pendampingan. Adapun tahapannya adalah :

\section{Persiapan Pembekalan}

Kegiatan pembekalan dalam pengabdian kepada masyarakat ini adalah metode workshop dalam bentuk pelatihan dan pendampingan sampai menghasilkan produk alat percobaan yang digunakan untuk memperoleh peningkatan kesadaran akan bahaya minuman keras jenis tuak dan arak. Kegiatan dilaksanakan selama 24 jam dengan struktur program yang dirincikan sesuai Tabel 2 berikut ini:

Tabel 2. Volume Program pelatihan perencanaan KIT praktikum untuk pembuktian bahaya miras

\begin{tabular}{clccc}
\hline No & $\begin{array}{c}\text { Materi } \\
\text { Pelatihan }\end{array}$ & $\begin{array}{c}\text { Jenis } \\
\text { Kegiatan }\end{array}$ & JKE & Peserta \\
\hline 1. & $\begin{array}{l}\text { Konsep dasar } \\
\text { sistem organ } \\
\text { tubuh dan }\end{array}$ & $\begin{array}{l}\text { Presentasi } \\
\text { dan Focus } \\
\text { Group }\end{array}$ & 2 JKE & 10 \\
\hline
\end{tabular}

Wedyawati \& Lisa, Peningkatan...20. 
http://jurnalstkippersada.acid/jurnal/index:php/JPMK

\begin{tabular}{|c|c|c|c|c|}
\hline No & $\begin{array}{c}\text { Materi } \\
\text { Pelatihan }\end{array}$ & $\begin{array}{c}\text { Jenis } \\
\text { Kegiatan }\end{array}$ & JKE & Peserta \\
\hline & $\begin{array}{l}\text { dampak buruk } \\
\text { karena minuman } \\
\text { keras }\end{array}$ & $\begin{array}{l}\text { Discusion } \\
\text { (FGD) }\end{array}$ & & \\
\hline 2. & Rancangan KIT & $\begin{array}{l}\text { Presentasi } \\
\text { dan Focus } \\
\text { Group } \\
\text { Discusion } \\
\text { (FGD) }\end{array}$ & $4 \mathrm{JKE}$ & 10 \\
\hline 3. & $\begin{array}{l}\text { Desain Alat } \\
\text { Evaluasi } \\
\text { Kegiatan }\end{array}$ & $\begin{array}{c}\text { Teori dan } \\
\text { Praktek }\end{array}$ & $2 \mathrm{JKE}$ & 10 \\
\hline 4. & $\begin{array}{l}\text { Pelaksanaan } \\
\text { Eksperimen }\end{array}$ & $\begin{array}{l}\text { Simulasi dan } \\
\text { Focus Group } \\
\text { Discusion } \\
\text { (FGD) }\end{array}$ & $4 \mathrm{JKE}$ & 100 \\
\hline 5. & $\begin{array}{l}\text { Evaluasi hasil } \\
\text { kegiatan }\end{array}$ & $\begin{array}{l}\text { Simulasi dan } \\
\text { Focus Group } \\
\text { Discusion } \\
\text { (FGD) }\end{array}$ & $2 \mathrm{JKE}$ & 10 \\
\hline 6. & $\begin{array}{l}\text { Evaluasi Kinerja } \\
\text { dan Produk }\end{array}$ & $\begin{array}{l}\text { Focus Group } \\
\text { Discusion } \\
\text { (FGD) }\end{array}$ & $2 \mathrm{JKE}$ & 10 \\
\hline \multirow[t]{2}{*}{7.} & Laporan kegiatan & $\begin{array}{l}\text { Teori dan } \\
\text { Praktek }\end{array}$ & $8 \mathrm{JKE}$ & 10 \\
\hline & Total & & 24 JKE & \\
\hline
\end{tabular}

Mekanisme pelaksanaan kegiatan

pengabdian kepada masyarakat melalui pemberdayaan mahasiswa PGSD dapat dilihat pada Gambar 1 sebagai berikut :
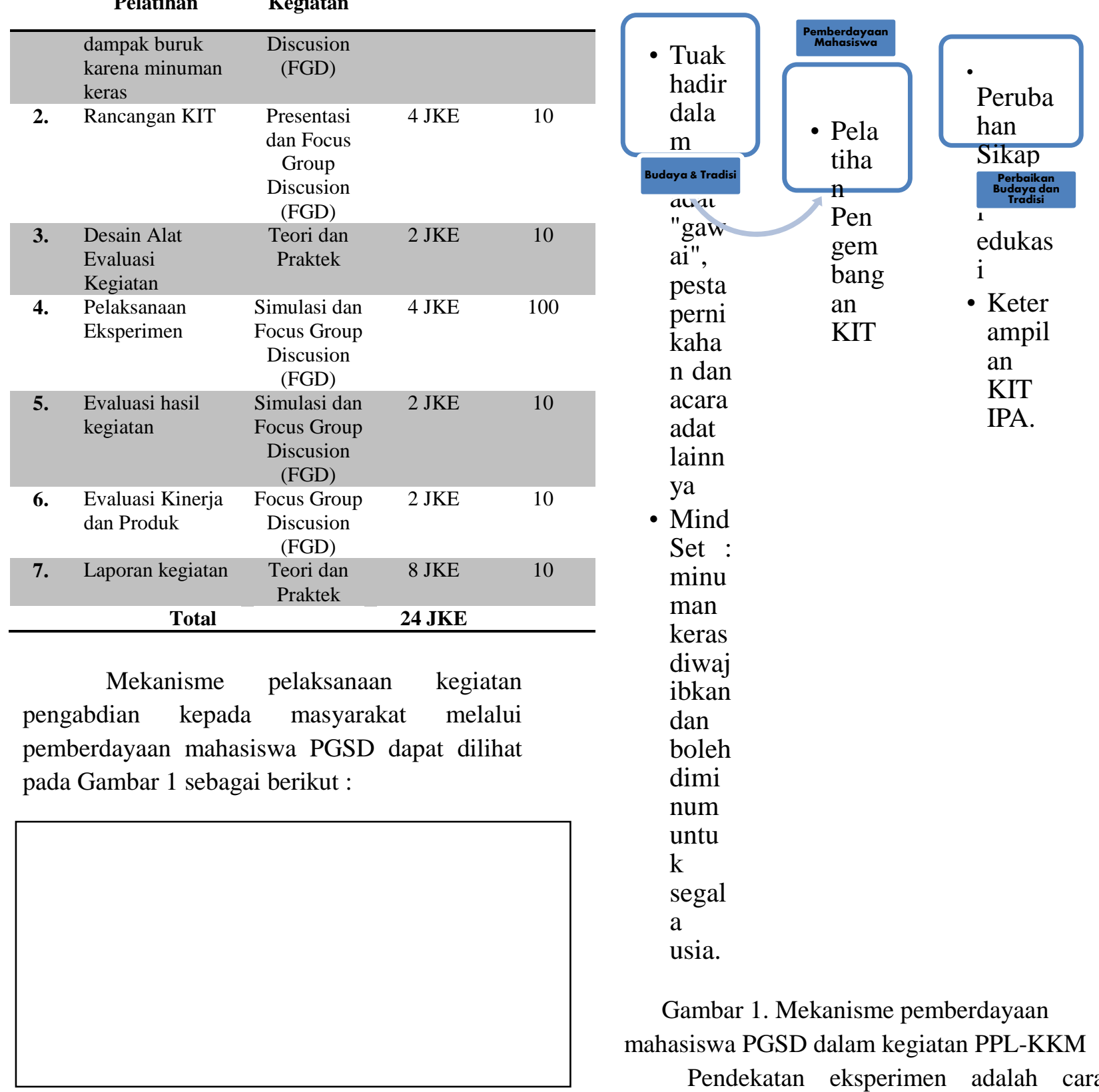

- Mind

Set :

minu

man

keras

diwaj

ibkan

dan

boleh

dimi

num

untu

$\mathrm{k}$

segal

a

usia.

Gambar 1. Mekanisme pemberdayaan mahasiswa PGSD dalam kegiatan PPL-KKM

Pendekatan eksperimen adalah cara pembuktian atau pembenaran sebuah konsep. Pendekatan ini akan membantu penyampaian kegiatan secara tidak langsung. Sehingga tidak akan terjadi pertentangan antara budaya dan larangan konsumsi arak/tuak.

Tahapan pelaksanaan kegiatan disajikan dalam tabel 3 berikut ini.

Tabel 3. Tahapan pelaksanaan kegiatan 


\begin{tabular}{|c|c|c|}
\hline No & Jenis Kegiatan & Bukti Dokumen \\
\hline 1 & $\begin{array}{l}\text { Koordinasi dan pendampingan } \\
\text { pelaksanaan pembuatan KIT }\end{array}$ & $\begin{array}{l}\text { Surat kesediaan } \\
\text { kerjasama }\end{array}$ \\
\hline 2 & $\begin{array}{l}\text { Pendampingan pembuatan dan } \\
\text { desain pembuatan KIT }\end{array}$ & $\begin{array}{l}\text { Daftar Hadir, Foto } \\
\text { Kegiatan dan Produk }\end{array}$ \\
\hline 3 & $\begin{array}{l}\text { Pendampingan Pembuatan } \\
\text { Petunjuk Praktikum }\end{array}$ & $\begin{array}{l}\text { Daftar Hadir, Foto } \\
\text { Kegiatan dan Produk }\end{array}$ \\
\hline 4 & $\begin{array}{l}\text { Koordinasi dan pendampingan } \\
\text { pelaksanaan kegiatan pada desa } \\
\text { sasaran }\end{array}$ & $\begin{array}{l}\text { Surat kesediaan } \\
\text { kerjasama }\end{array}$ \\
\hline 5 & $\begin{array}{l}\text { Pendampingan dan pelaksanaan } \\
\text { kegiatan }\end{array}$ & $\begin{array}{l}\text { - Penilaian Kinerja. } \\
\text { - Angket. } \\
\text { - Daftar hadir } \\
\text { - foto kegiatan }\end{array}$ \\
\hline 6 & $\begin{array}{l}\text { Analisis Peningkatan Kesadaran } \\
\text { bahaya minuman miras }\end{array}$ & - Angket. \\
\hline 7 & Sosialisasi & Publikasi \\
\hline
\end{tabular}

Indikator capaian keberhasilan kegiatan pengabdian ini adalah :

a. $99 \%$ Mahasiswa hadir dalam pelatihan

b. $80 \%$ peserta memiliki perubahan pemahaman tentang bahaya mengkonsumi minuman keras diukur dengan angket

c. Terlaksananya seluruh kegiatan

Karena kegiatan ini menggunakan pendekatan eksperimen maka teknologi yang dikembangkan adalah mengembangkan KIT Praktikum untuk dijadikan sarana pembelajaran dan pembuktian bahwa minuman keras dapat merusak tubuh dan organ penting manusia. Keterampilan yang diajarkan adalah keterampilan membuat alat, Lembar Kerja Praktikum dan alat evaluasi kegiatan.

Khalayak sasaran yang strategis dalam kegiatan ini adalah mahasiswa PGSD pada program PPL \& KKM serta anak-anak usia sekolah dasar di desa Bora kecamatan Sayan Kabupaten Melawi.

\section{HASIL DAN PEMBAHASAN}

E-ISSN 25E0-5300

Pendampingan dan pelatihan mahasiswa PGSD dalam mengimplementasikan KIT IPA sebagai pendekatan praktikum guna menunjukkan bahaya minuman keras bagi tubuh manusia.

Kegiatan pendampingan dan pelatihan di laksanakan pada tanggal 7 November 2019 pada pukul 09.00 - 12.00 Wiba di desa Bora kecamatan Sayan Kabupaten melawi. Kegiatan dihadiri oleh peserta pelatihan yaitu mahasiswa PGSD yang menjadi peserta PPL dan KKM terpadu pada tahun akademik 2018/2019. Dalam kegiatan ini indikator keberhasilan adalah $99 \%$ peserta hadir dalam kegiatan. Indikator tersebut tercapai, semua peserta yang hadir dalam kegiatan tersebut.

Dalam pelaksanaan ini juga dievaluasi dengan angket kepuasaan peserta terhadap kegiatan dengan indikator-indikator pernyataan adalah

a. kemampuan pemateri pelatihan dalam menyampaikan materi dengan komponen penilaian adalah pemateri menguasai materi, komunikatif, menarik, presentasi audiovisualnya menarik, tepat waktu dan memberi kesempatan untuk diskusi, tujuan kegiatan jelas, relevan dengan PGSD, bermanfaat untuk mahasiswaa, sesuai dengan harapan peserta, cakupan materinya memadai dan sesuai dengan perkembangan di praktisi pendidikan.

b. Suasana kegiatan dinilai dengan komponen; kegiatan tidak membosankan, banyak diskusi dan tepat waktu.

c. Sarana dan prasarana Kit lengkap, rehat kopi dan makan siang memadai.

Hasil perolehan dari angket disajikan dalam tabel 4 dengan rata-rata total perolehan adalah 47.1 dengan kategori sangat baik. Artinya kegiatan pendampingan dan pelatihan ini terlaksana dengan sangat baik. 
Tabel 4. Rekapitulasi Hasil kepuasan Kegiatan Pendampingan

\begin{tabular}{|c|c|c|}
\hline No & Indikator & $\begin{array}{l}\text { Skor } \\
\text { Total }\end{array}$ \\
\hline \multicolumn{3}{|c|}{ MATERI } \\
\hline 1. & Jelas dan mudah diikuti & 43 \\
\hline 2. & Relevan & 43 \\
\hline \multicolumn{3}{|c|}{ FASILITATOR } \\
\hline 3 & Penguasaan Materi & 42 \\
\hline 4 & Gaya Penyampaian & 42 \\
\hline 5 & Kejelasan dalam Penyampaian & 43 \\
\hline 6 & Kemampuan menjawab Pertanyaan & 43 \\
\hline 7 & Penampilan & 42 \\
\hline \multicolumn{3}{|c|}{ SARANA } \\
\hline 8 & Kenyamanan & 42 \\
\hline \multicolumn{3}{|c|}{ KONSUMSI } \\
\hline 9 & Snack & 42 \\
\hline 10 & Makan Siang & 42 \\
\hline \multicolumn{2}{|c|}{ KESIMPULAN } & 44 \\
\hline \multicolumn{2}{|c|}{ Skor Total } & 424 \\
\hline \multicolumn{2}{|c|}{ Rata-Rata } & 47,1 \\
\hline
\end{tabular}

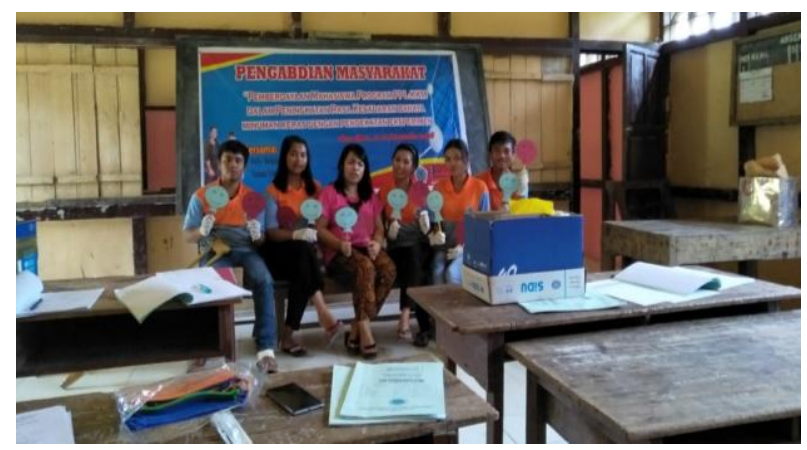

Gambar 2. Kegiatan Pelatihan peserta mahasiswa PGSD

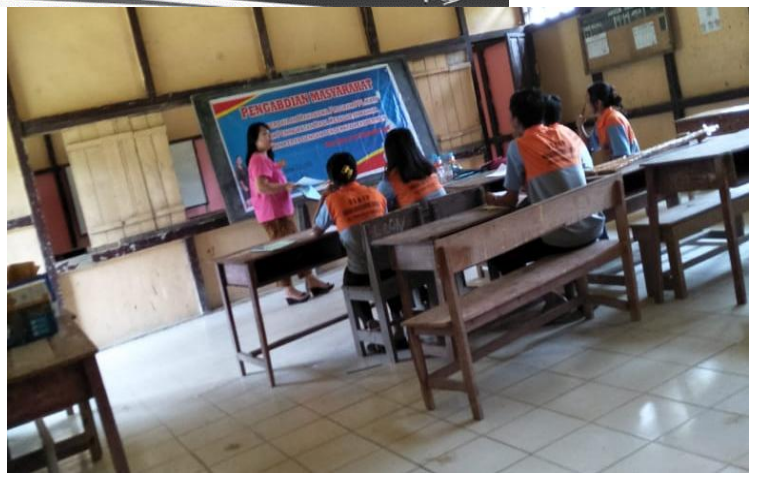

Gambar 3. Kegiatan Pelatihan peserta mahasiswa PGSD

Peningkatan kesadaran bahaya minuman keras bagi tubuh pada peserta didik sebagai sasaran utama dengan pendekatan eksperimen terintegrasi kegiatan KKM mahasiswa PGSD.

Jumlah peserta yang hadir adalah 63 orang siswa yang terdiri dari kelas IV, kelas V dan Kelas VI. Implementasi eksperimen dilaksanakan dengan pembagian menjadi 3 kelas masing-maisng kelas di dampingi oleh mahasiswa sebagai pelatih eksperimen. Karena para mahasiswa PGSD sudah menerima pelatihan pada sesi kegiatan I. Dari hasil kegiatan diperoleh angka angket adalah 63 jawaban ya dengan presentase 100. Artinya siswa sekolah dasar mengetahui bahwa minuman keras merusak darah, hati, ginjal dan tulang. Perolehan hasil disajikan dalam Tabel 5.

Tabel 5. Peningkatan kesadaran peserta kegiatan dan keberterimaan Program Kegiatan.

\begin{tabular}{llll}
\hline No. & Pernyataan & Ya & Tidak \\
\hline MATERI & & \\
1. & Menarik & 63 & \\
2. & Bermanfaat & 63 & \\
MINUMAN KERAS & & \\
3. & Boleh diminum & 63 \\
4. & Merusak Hati & 63 \\
5. & Merusak Tulang & 63 \\
6. & Merusak Darah & 63 \\
\hline
\end{tabular}


Keberterimaan peserta didik pada program KKM-PKM di desa Bora

Penyebaran angket selain untuk mengetahui peningkatan pemahaman siswa tentang bahaya minuman keras juga dilakukan untuk memperoleh informasi apakah kegiatan ini disukai oleh sasaran kegiatan, yaitu siswa sekolah dasar. Hasil menunjukkan angka 100\% (63) bahwa kegiatan yang telah dilaksanakan masuk dalam kegiatan yang dianggap menarik dan bermanfaat bagi siswa. Perolehan hasil keberterimaan kegiatan disajikan dalam tabel 5.

Ketertarikan dan motivasi untuk mendapatkan pengetahuan dari siswa ternyata cukup tinggi hal ini ditunjukkan dari hasil angket dari Tabel 5, dimana semua siswa setuju bahwa materi yang disampaikan sangat bermanfaat dan menarik. Keikutsertaan siswa dalam bereksperimen di kelas ditunjukkan pada Gambar 4 dan Gambar 5.

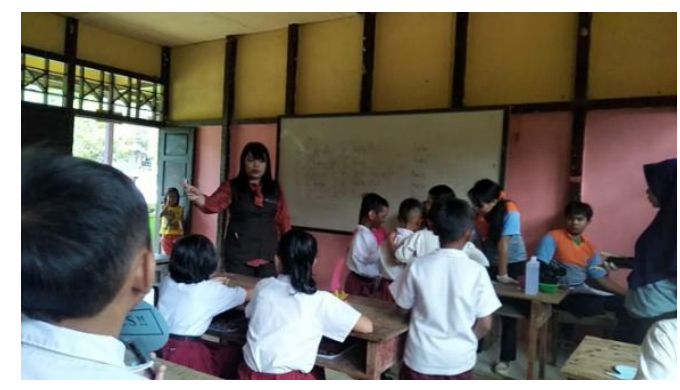

Gambar 4. Eksperimen minuman keras merusak tubuh

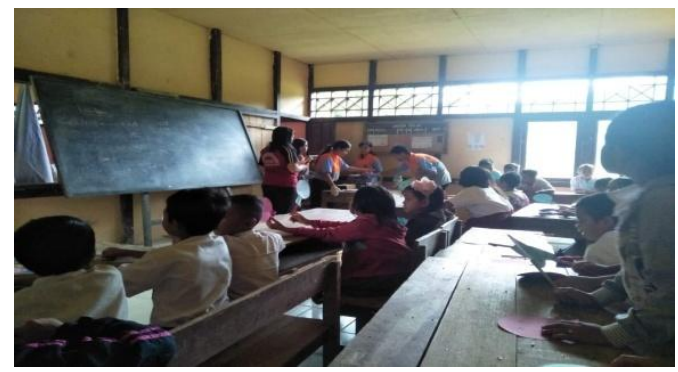

Gambar 5. Eksperimen minuman keras merusak tubuh

\section{KESIMPULAN}

Kesimpulan dari kegiatan ini dituliskan dalam poin-poin berikut ini:

a. Keterampilan mahasiswa PGSD dalam mengimplementasikan kit IPA sebagai pendekatan praktikum guna menunjukkan bahaya minuman keras bagi tubuh manusia melalui kegiatan pelatihan dan pendampingan berkategori sangat baik dengan nilai rata-rata adalah 98. Dengan kehadiran mahasiswa adalah $99 \%$.

b. Terdapat peningkatan kesadaran bahaya minuman keras bagi tubuh pada peserta didik sebagai sasaran utama dengan pendekatan eksperimen terintegrasi kegiatan KKM mahasiswa PGSD dengan angka 45, diketahui skor pengetahuan awal sebelum eksperimen adalah 55 dan skor setelah kegiatan pengabdian adalah 100. Artinya seluruh siswa yang menjadi sasaran kegiatan telah memiliki kesadaran bahaya minuman merusak organ tubuh manusia.

c. Keberterimaan peserta didik pada program KKM-PKM di desa Bora memperoleh 100 , artinya semua siswa menyenangi kegiatan pengabdian dengan tema eksperimen minuman keras merusak organ tubuh manusia.

\section{SARAN}

Saran-saran yang dituliskan dalam laporan ini berdasarkan pada temuan kelemahankelemahan selama kegiatan pengabdian berlangsung yang dituliskan sebagai berikut:

a. KIT dalam kegiatan masih bersifat sederhana dan minimalis, diharapkan dapat diciptakan KIT lainnya berbasis IT atau KIT berbasis Visual 3D. 


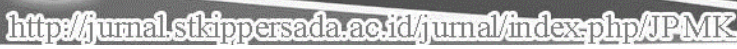
e-ISSN 2550-5300

b. Kegiatan yang sama dapat dilaksanakan Kempton, J. 1995. Human Resource pada sasaran yang lebih luas contohnya jumlah siswa yang lebih banyak, usia siswa yang jenjangnya lebih tinggi dan masyarakat umum.

\section{DAFTAR PUSTAKA}

Ellis, G.F.R. 1984. The Dimension of Poverty dalam Social Indicator Research

Esmara, H. 1986. Perencanaan dan Pembangunan di Indonesia, Jakarta: Gramedia 